UDC 821.163.41-14.09 Preradović P.

$011 / 016(=163.41)$

https://doi.org/10.18485/ms_zmskij.2020.68.3.3

Весна М. Тријић

\title{
ПЕТАР ПРЕРАДОВИЋ У СРПСКОЈ РЕТРОСПЕКТИВНОЈ БИБЛИОГРАФИЈИ И КЬИЖЕВНОЈ ИСТОРИЈИ
}

На примеру положаја који у српској ретроспективној библиографији и књижевној историји заузима дело романтичарског песника Петра Прерадовића, Србина из Хрватске, римокатоличке вероисповести и заговорника југословенске идеје, показаћемо логику и последице процеса радикалног сужавања концепта српског националног идентитета током 20. века. Уместо на разликама између српског и хрватског модела националне културе, задржаћемо се на идеологији коју је српска култура испољавала кроз променљив однос према Прерадовићу.

Кључне речи: Петар Прерадовић, национални идентитет, српска ретроспективна библиографија, национална књижевна историја.

Српска национална библиографија и књижевна историја су, од својих почетака, крајем 18. и почетком 19. века, биле у нераскидивој вези: усмерене на проучавање културне прошлости - библиографија као „попис душа“ и „статистика злијех и добријех дјела“ (НовАковић 2001: v), а књижевна историја као наратив који тумачи и валоризује њену грађу - давале су комплементарне одговоре на питања о корпусу националне културе, а самим тим и о оквирима националног идентитета. Стога су библиографи и књижевни историчари одувек сарађивали, размењујући сазнања а у извесној мери се и међусобно идеолошки усмеравајући.

Национални идентитет, међутим, није метафизичка, једном занавек дата категорија, већ идеолошки конструкт, йрича која се постепено мења, у зависности од политичких и културних преокупација епохе. Та законитост је на примеру српског националног идентитета нарочито видна: друштвено-политичка и културно-историјска динамика 20. века, најпре у југословенском а онда и у глобалистичком идеолошком контексту, водиле су језичком и верском комадању етничке базе српске нације; делови културне баштине везани за територије некадашњих југословенских република најпре су на 
различите начине дистанцирани од својих културних корена, а затим асимиловани култури ,домаћина“" и на тај начин - денационализовани (ИвАнић 1998; ТутњЕВИЋ 2004).

Логику и последице овог културноисторијског процеса показаћемо на примеру песника Петра Прерадовића, односно његовог положаја у српској ретроспективној библиографији и књижевној историји.

Петар Прерадовић ${ }^{1}$ је крајишки Србин, рођен 1818. године, у православној породици, од оца Јована и мајке Пелагије, у селу Грабровница, у општини Грубишно Поље. Током осмогодишњег школовања на Војној академији у Винер Нојштату, чији су питомци били римокатоличке вероисповести, био је покрштен ${ }^{2}$ и од матерњег језика се удаљио довољно да је своје прве песме писао на немачком. На Академији је, истовремено, дошао под утицај идеја панславизма: наставник чешког језика био му је Томаш Буријан, доцнији оснивач Матице чешке, који је своје ученике васпитавао у духу идеја Јана Колара (VoDNIK 1918), а онима који су међу њима били српске и хрватске националности давао Вукове збирке народне поезије (ИвАнић 1998).

Доцнији Прерадовићев песнички развој одвијао се у хрватској културној средини и у духу илиризма. Једине две збирке које је објавио за живота, Pervenci (1846) и Nove pjesme (1851), штампане су у Загребу, латиницом. Треба, међутим, нагласити да је прва од њих посвећена „krasnome spolu jugoslavjanskog naroda“ (PRERADOVIĆ 1846), који је, према песниковом уверењу, требало да настане обједињавањем српског и хрватског племена, а друга Јосипу Јурају Штросмајеру, у то време такође гласовитом заговорнику југословенства. Прерадовић се у различитим документима декларисао и као Србин и као Хрват, јер је ту разлику, у складу са идејама којима је био надахнут, сматрао небитном, сувишном, чак и будаластом; ${ }^{3}$ његово културно становиште није, дакле, било српско-хрватско, већ југословенско, унитаристичко. То му је, међутим, у пракси донело само амбивалентност: поводом исте збирке, Pervenaca, дописивао се са Вуком Караџићем, најављујући њено ћирилично издање, до којег никада није дошло, и добио Златну медаљу Literaria et artibus од аустријског цара Фердинанда I (Građa za leksikon pisaca Jugoslavije 2014).

\footnotetext{
${ }^{1}$ Извори за биографију Петра Прерадовића наведени су на крају текста.

2 Насупрот тврдњи да је Прерадовић у школске књиге заведен као римокатолик по аутоматизму, без претходног обреда покрштавања (ГАвриловић 2008), постоји податак да је до тога заиста дошло, 8. августа 1832, када је будућем песнику било четрнаест година (РАдолчић 2009). Доцније његово одавање спиритизму тумачено је као „posljedica neukorenjenosti u vjeri na koju je prešao u vojnoj školi““ (PEJović 1973: 92).

3 У писму Игњату Брлићу, 1863, Прерадовић каже да се нада оснивању политичке партије која би прогласила будалом свакога ко тражи разлике између Срба и Хрвата (Шевић 1902; БАртУЛОВИЋ 1918).
} 
Иако су га животне околности српској средини увек бар у извесној мери чиниле страним, то не значи да Прерадовић није био везан и за српску, а не само за хрватску културу: он је то био пре свега језиком своје поезије - као и сви српски писци у Хрватској, од Саве Мркаља и Сима Матавуља до Владана Деснице, користио је штокавско наречје ијекавског изговора - затим личностима и догађајима из српске историје и предања које је у својој поезији тематизовао, као и сарадњом са српским књижевним часописима; своје родољубиве стихове посвећивали су му Јован Јовановић Змај и Алекса Шантић. Упркос томе, Прерадовић је у историјама наше књижевности остао рубна, а самим тим и мање важна појава, чије се присуство констатује, али не и проучава; Стојан Новаковић, у оба издања своје Истиорије срииске књижевнос $\bar{u} u$, о њему чак говори као о далматинском књижевнику ${ }^{4}$ (Новаковић 1867: 242; Новаковић 1871: 299); Јован Скерлић га у Истиорији нове срйске књижевностии (1914) и не спомиње.

У хрватској традицији тумачења Петра Прерадовића, с друге стране, могу се уочити следеће константе: ${ }^{5}$ песниково национално порекло најчешће се не спомиње или се то чини заобилазно, повезивањем са Војном крајином, која је географско, али не и етничко одређење идентитета; ${ }^{6}$ име песниковог оца појављује се једино у похрваћеној варијанти, Иван; Прерадовићев матерњи језик упорно се назива хрватским; упоредо са умањивањем значаја Шпира Димитровића Которанина (који се, ако је споменут, такође проглашава Хрватом) и потпуним прећуткивањем Прерадовићевих контаката са Вуком Караџићем, истиче се утицај Ивана Кукуљевића Сакцинског као пресудан за песников повратак народном језику (BARAC 1964). За онај део Прерадовићевог опуса који је у тематској, а самим тим и у непорецивој вези са српском традицијом, хрватски књижевни историчари имају три „приступа“: игноришу га, ${ }^{7}$ вредносно потцењују, одбацују ${ }^{8}$ или га тумаче у наглашено славе-

4 До ове грешке је највероватније дошло зато што је Прерадовић, као аустријски официр, једно време службовао у Задру (1843-1847), где је био и уредник Зоре gалмайинске, у којој је објавио своју прву песму на матерњем језику, „Зора пуца“ (Građa za leksikon pisaca Jugoslavije 2014).

${ }^{5}$ Избор из хрватске литературе о Прерадовићу налази се на крају текста.

6 Занимљиво је да смо у хрватским изворима на податак о Прерадовићевом експлицитно српском пореклу наишли у прошлогодишњем чланку посвећеном обнови Прерадовићеве родне куће, коју је финансирао Европски фонд за регионални развој (GAZDEK 2019). Важно је, међутим, приметити да је до тога дошло у оквиру транснационално конципираног пројекта „Прерадовић и Чоконај - прослава песника романтизма у пограничном подручју”, у којем национални и историјски односи више нису ни од каквог значаја.

7 Јакша Равлић је, на пример, у зборнику Пештар Прераgовић gанас (1970), писао само о Хрватима које је Прерадовић опевао у циклусу Милим йокојником, игноришући његов „српски део“, у којем су песме посвећене Његошу, Бранку Радичевићу, Стевану Книћанину, Јосифу Рајачићу, Шпири Димитровићу и кнезу Михајлу Обреновићу.

${ }^{8}$ Иво Франгеш, на пример, каже да у незавршеној драми Марко Краљевић, која је по Јовану Деретићу била песниково главно дело, не треба тражити праву вредност Прерадовићеве 
нофилском кључу, као да је последица идеолошке а не урођене песникове склоности српским темама (BARAC 1964). Током 20. века је, међутим, било и покушаја релативизовања па и порицања Прерадовићеве књижевне вредности и културноисторијског значаја, што Душан Иванић доводи у везу управо са овом, „српском компонентом“ његовог опуса и тумачи као „значајан индикатор обрта у судбини српске књижевности на просторима Крајине“ (1998: 13).

Данас је Петар Прерадовић хрватски национални бард, највећи песник илиризма и творац ,tipa pjesničkog jezika hrvatskog koji je vladao sve do Kranjčevića“" (Frangeš 1970: 10). Кости су му од 1879. на Мирогоју, у Загребу, а његова родна кућа је обавезно одредиште екскурзија хрватских школараца. Један од омиљених престоничких тргова (некадашњи Трг братства и јединства) данас носи песниково име (мада га Загрепчани радије називају Цвјетним тргом, по локалној цвећари) и обележен је његовим спомеником, изванредним делом вајара Ивана Рендића, на самом улазу у православну цркву Преображења Господњег.

Шта то заиста значи, показују примери из две најновије нама познате концептуализације српске и хрватске књижевности - у Лексикону јужнословенских књижевностии (Г. Я. Ильина, ред. 2012), коју су приредили сарадници Института за славистику Руске академије наука, и у вишетомној Истиорији

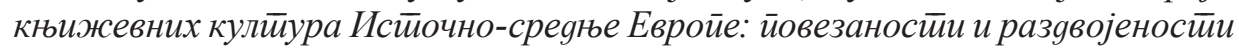
y 19. и 20. веку (M. Cornis-Pope and J. Neubauer, eds.), која је резултат рада међународног тима координираног из Универзитета у Торонту.

У обе ове књижевне историје се, наиме, о Петру Прерадовићу говори као о искључиво хрватском песнику. Упркос томе што је Лексикон, према предговору Галине Иљине, методолошки утемељен на појму билитерарности, који подразумева да опус једног писца може да припада двема књижевним традицијама, у којима има различито место и значење, овај принцип у Прерадовићевом случају није примењен: ${ }^{9}$ он је искључиво хрватски песник (ЛЕксикон 2012: 359), а не један од стваралаца у чијем се опусу одвија дијалог двеју суседних књижевних традиција. Овај тренд је у Истиорији књижевних кулйура доведен до апсурда, јер један од њених уредника, Џон Нојбауер, Прерадовића експлицитно и не назива хрватским песником, већ Хрватом, супротстављајући га Бранку Радичевићу и Јовану Стерији Поповићу као Србима (HISTORY 2007: 14, 282).

поезије (FRANGEŠ 1970; Деретић 1996). Занимљиво је и да се Џон Нојбауер управо на овој Прерадовићевој драми задржава као на индикативној за идеолошка и културна струјања на Балкану у 19. веку, поредећи Прерадовићеву и Стеријину интерпретацију епског јунака (HISTORY 2007).

${ }^{9}$ Колико је ова недоследност руских приређивача необична, најбоље сведочи сам контекст Лексикона, у којем се у примени принципа билитерарности повремено ишло и у такве крајности да је Мак Диздар, на пример, одређен као „боснийско-герцеговинский бошнятский поэт, считавший себя также и хорватским поэтом“ (ЛЕКСикон 2012: 110). 
У Срйској библиоірафији. Кюиїе 1868-1944, део Прерадовићевог опуса из овог периода заступљен је са свега пет библиографских јединица (69.77169.775). Посреди су четири ћириличне и једна латинична публикација, која је штампана у Београду, односно књиге штампане у Србији, осим Анйолоіије Бранка Водника, коју је Народна књижница у Загребу 1922. године штампала ћирилицом.

Дакле, у Срйску библиоірафију су уврштена само она Прерадовићева дела која су, у обухваћеном периоду, штампана у Србији и(ли) ћирилицом.

Ову слику донекле мења претрага кроз свих двадесет томова Срйске библиоірафије преко предметног регистра, која је дала 34 поготка. У питању су претежно антологије и календари, у којима се Прерадовићева лирика појављује у југословенском и српском културном контексту. Вреди издвојити Илустировану срйску нарояну лиру (недатирано издање Српске књижаре и штампарије Ј. Радака из Велике Кикинде), јер је њен анонимни приређивач Прерадовића уврстио међу лиричаре чије су песме у српском народу омиљене, те се и певају. Приметан је, међутим, и другачији пример: Јеремија Живановић у својим Примерима нове књижевностии (Београд: Издавачка књижарница Геце Кона, 1928), Прерадовићеве песме, од којих је једна на немачком, даје латиницом, док је састав Огњеслава Утјешеновића Острожинског, још једног српског илирца, штампан ћирилицом.

Остале књиге су, претежно, биографске природе: у њима је Прерадовић уврштен међу знамените Србе свог доба и међу утемељиваче југословенске идеје. Најзанимљивији такви наслови су Знаменийи Срби XIX века Андре Гавриловића (Загреб: Наклада српске штампарије, 1903) и Поменик знамени-

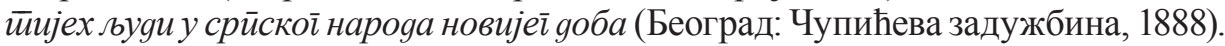

Када се ова два невелика списка упореде, логички несклад међу њима постаје очигледан: ако је Прерадовић међу знаменитим Србима 19. века, зашто се у српској националној библиографији нашао само преко формалних критеријума, писма и територије на којој су му дела штампана? Одговор треба тражити у тужној и мучној историји пројекта српске ретроспективне библиографије.

Није нимало случајно што је Комисија за израду ретроспективне српске библиографије ${ }^{10}$ свој рад отпочела 1954: била је то, наиме, година потписивања Новосадског књижевног договора, којим су српски и хрватски језик „на папиру“ били уједињени, у српскохрватски. Циљ Комисије било

10 Чланове Комисије за израду ретроспективне српске библиографије именовао је Савет за просвету и културу НР Србије; то су били: Борислав Благојевић (професор Правног факултета Универзитета у Београду, председник Комисије), Милица Продановић (управница Универзитетске библиотеке „Светозар Марковић“), Смиља Мишић (управница Централне библиотеке САН), Душан Милачић (управник Народне библиотеке), Милутин Иванушић (директор Библиографског института ФНРЈ), Едиб Хасанагић (управник Државне архиве НР Србије) и Драги Миленковић (народни посланик). 
је окупљање водећих републичких библиотечких центара ради састављања државне библиографије која је, уз Енииклойеgију Jуїославије и Новосадски књижевни договор, требало да буде израз уједињења југословенског културног простора. Стога тема на састанцима Комисије, како записници показују, ${ }^{11}$ нису ни били критеријуми за израду библиографије, већ платформа за њено објављивање: требало је наїоворитии Загреб и Љубљану, који су се пре тога на институционализован начин већ бавили израдом својих националних библиографија (Хрвати од 1941, Словенци од 1951), да одустану од националних критеријума и замене их територијалним, како би све републичке библиографије накнадно могле да буду обједињене регистрима и заједничким издањем. Преговоре, записници и то посредно откривају, библиографи нису ни водили, већ су то уместо њих чиниле истакнуте политичке фигуре: Родољуб Чолаковић, председник Извршног већа ФНРЈ, договорио је платформу са Јосипом Видмаром и Мирославом Крлежом, директором Лексикографског завода, којег је на састанцима представљао Мате Ујевић. ${ }^{12}$ Право Хрвата на националну библиографију бранио је директор Свеучилишне књижнице Матко Ројнић, који је неколико година раније, у сарадњи са Евом Вероном, и формулисао њене критеријуме (HARNI 2004).

Српска страна, по свему судећи, на своју националну библиографију није ни помишљала, већ је републичку библиографију, засновану на територијалном критеријуму, упорно називала националном; национално порекло аутора узимано је у обзир за дела штампана у иностранству, али не и за она која су штампана у осталим социјалистичким републикама. ${ }^{13}$ То је значило да се производи интелектуалног рада Срба који живе и стварају на тим територијама - а данас су то све самосталне државе - ирейущuйају тамошњим библиографским центрима. Дело Петра Прерадовића је један од таквих „случајева“.

11 Документација Комисије налазе се у архиви Народне библиотеке Србије, као необрађени материјал; коришћене записнике смо навели на крају рада.

12 Мате Ујевић је био главни уредник Хрвайске енцииклойеgије. Према Славку Харнију, библиотекару Националне и свеучилишне књижнице у Загребу, циљ Ујевићевог ангажовања у изради југословенске библиографије није био ,, jezički serbokroatizam“, већ промовисање Лексикографског завода „u kojem će se proučavati sve nacionalne jugoslavenske bibliografije kulture i tako potvrditi Zagreb kao središte Jugoslavije“ (HARNI 2004: 72).

13 У предговору првом тому Срйске библиоірафије. Кюиіе 1868-1944 (1989), главни редактор Миодраг Живанов наводи критеријуме за одређивање опсега библиографије које је формулисала Комисија: „a) Све књиге штампане на територији Народне републике Србије без обзира на језик, писмо или национално порекло аутора; б) све књиге аутора српског порекла штампане ван граница Југославије без обзира на језик; в) све књиге штампане ван граница Југославије на српскохрватском језику без обзира на национално порекло аутора; г) сва издања Српске академије наука и уметности и Српске књижевне задруге штампана на територији неке наше друге републике; д) издања Народног дела штампана у Загребу; ђ) издања издавача из Србије штампана у штампарији Ново доба у Вуковару од 1918. до 1930. године“" (Живанов 1989: xvii). 
За Библиографско одељење Народне библиотеке Србије, које је 1960. године преузело задатке до тада већ расформиране Комисије, почеле су туробне деценије, испуњене притисцима професионалне савести са једне и страховима од могућих оптужби за национализам и сепаратизам са друге стране.

О дубини проблема можда најречитије сведочи новински чланак некадашњег начелника Одељења (1971-1973), књижевног историчара Драгише Витошевића, који је објављен у божићном културном додатку Полийике 1984. године. Он ту износи поражавајући податак да је рад на Срйској библиоірафији 1868-1944 завршен још 1976. (!), али да нема политичке дозволе за њено објављивање. „Библиографско одељење Народне библиотеке упорно упућује разне дописе и дозиве, али - одговора нема. Штавише, овај посао је неким чудом 'испао' и из списка капиталних дела“, пише у том чланку. Витошевић, што је можда и најважније, открива да разлоге за то треба тражити у страху „од самог појма 'национална библиографија'“ и, уже од тога, од разграничавања у области контаката суседних националних култура: „У

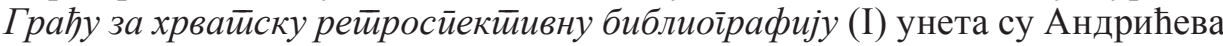
дела штампана у Београду 1920-22. године, када је он сматран српским писцем, али зашто би то морало сметати?“ (Витошевић 1984: 10).

Да би дубина и озбиљност проблема на који је Драгиша Витошевић указао била на прави начин схваћена, потребно је нагласити да је у време објављивања овог његовог чланка, Građa za hrvatsku retrospektivnu bibliografiju, сасвим неометано, излазила већ две године.

Од Преgі̄овора Миодрага Живанова првом тому Срйске библиоірафије (1989), уобичајено је да се због неуспеха пројекта југословенске државне библиографије посредно жали, ${ }^{14}$ као да је то што је пропао, а не то што је уопште постојао и што се на њега пристало, угрозило израду српске ретроспективне библиографије. На њене ће нас контроверзне идеолошке почетке увек подсећати абецедни распоред библиографских јединица, добровољни принос

${ }^{14}$ Између редова текста Преgі̄овора Миодрага Живанова, који је у изради Срйске библиоірафије учествовао још од 1960, може се прочитати незадовољство односом који су хрватски и словеначки библиографски центри имали према пројекту југословенске библиографије. Приметно је, такође, да је Живанов окретање Народне библиотеке Србије од територијалног ка територијално-националном принципу на првом месту мотивисао тиме што су Македонија и Босна и Херцеговина одустале од пројекта југословенске библиографије, поводећи се за хрватским и словеначким примером (што значи да је Србија у инсистирању на југословенској библиографији остала потпуно усамљена), а тек на другом месту сумњом „да ће библиографија заснована само на територијалном принципу моћи да удовољи свим захтевима наше науке“ (ЖивАнов 1989: хіх). Исти односи владали су и у књижевним питањима: док су српски писци претежно били мишљења да су поједине литературе народа и народности СФРЈ само делови интегралне, југословенске, „друго становиште, етикетирано као сепаратистичко, заступали су хрватски и словеначки писци, да би им се касније придружили у већини и писци других народа и националних мањина (народности)““(ДЕРетић 1996: 168). 
планираном обједињавању републичких библиографија у државну, до којег није дошло. А судећи према грађи из првих двадесет томова, замена територијалног критеријума национално-територијалним остала је нејасна, па је и његова примена била конфузна; корпус српске књиге у њима је ужи и од Исйорије срйскої нароgа (СКЗ, 1981-1993) и од Исйорије срйске књижевностии Јована Деретића (1983).

Већина значајних текстова српских аутора у 20. веку о Петру Прерадовићу настала је или у време стварања Југославије ${ }^{15}$ или након њеног распада; у међувремену, на научним скуповима и у пратећим зборницима поводом јубилеја песниковог рођења излагали су једино хрватски књижевни историчари. ${ }^{16}$

Важно је, осим тога, нагласити и да су радови српских аутора ретко када били усмерени на Прерадовићево уметничко дело; више их је занимала песникова биографија и његов контроверзни културнополитички ангажман. Циљ већине наших аутора био је да отклоне сваку недоумицу у погледу песниковог српског порекла; стога су се задржавали на именима његових предака и потомака, трошили су се на доказивање његове православности, бавили се чак и порицањем чињенице да се Прерадовић није декларисао само као Србин већ и као Хрват.

Први покушај повратка Прерадовића у историју српске књижевности збио се 1971. године, када је Станко Кораћ, у споменици Српског културног друштва Просвјета, Вјейром вијани, без пропратног коментара, у одељку „Књижевни прилози“, објавио три његове песме са темама из српске историје: „Косово поље“, „Цар Душан“ и „Милим покојником (кнезу П. Петровићу Његошу)“.

Нарочиту тежину овом Кораћевом поступку придаје културнополитички контекст објављивања споменице, обележен деловањем Маспока, које из данашње перспективе делује као претходница грађанског рата; Матица

\footnotetext{
${ }^{15}$ Издвојили бисмо есеј Милана Кашанина, O Petru Preradoviću, povodom njegove stogodišnjice rođenja, објављен у Ljubljanskom zvonu, у којем се млади Кашанин, као још један Србин Пречанин, поистовећује са Прерадовићем, називајући га ,jednim od najvećih pesnika jedinstva Hrvata i Srba“, чији је национализам ,prelazio granice jedne uske pokrajine i obuhvatio čitav naš troimeni narod“ (KAŠANIN 1918: 249); у истом надахнућу је о Прерадовићу као песнику југословенског јединства писао и Александар Арнаутовић: „Quand d la Yougoslavie aura élevé, dans la Plaine de Kossovo, son Temple National, que notre grand maître Mechtrovitch rêve, elle y mettra la statue de Préradovitch à côté de celle du chantre national, de nothre Gouslar“" (1919:27).

${ }^{16}$ Није на овом месту сувишно ни подсетити да је државна Комисија за израду уџбеника историје књижевности 1949. године прописала „не само да се дубровачка књижевност не сме сагледавати као регионална и посебна књижевност нити, пак, изван хрватске књижевности [него и да] о овом раздобљу, о епохи и појединим писцима, треба да пишу књижевни хисторичари из Хрватске“ (ЛомпАР 2017: 121).
} 
хрватска је тада одбацила Новосадски књижевни договор и објавила правопис хрватског језика. Кораћев предговор споменици је, стога, био полемички интониран, те данашњем читаоцу говори о егзистенцијалној угрожености српске мањине у ондашњој, авнојевској Хрватској. Он сведочи да се политичка и културна историја Срба, у капиталним хрватским издањима, криви и прекраја, да се усташки злочини прећуткују и заташкавају, као и да је Српско културно друштво Просвјета, у финансијском погледу, препуштено само себи. У таквој атмосфери, Кораћева намера је „да макар фрагментарно задовољи многе празнине у познавању културне и политичке историје Срба у Хрватској“, да укаже „на учешће Срба из Хрватске у књижевном и духовном развитку Срба и Хрвата“" $(1971: 6,7)$, али и да наиђе на одобравање и моралну подршку Пречана, и да их на тај начин идеолошки сабере и уједини.

Осам година касније, у Книжевној хресӣомайији: из кулимурне бащйине срйскоі нароgа у Хрвайској (1979), Кораћ почиње да развија критеријуме за разграничавање српске и хрватске књижевности, али то ради посредно, задржавајући се пре свега на филолошком критеријуму. Он подсећа да су хрватски матични дијалекти чакавски и кајкавски, те да је опредељење илираца за штокавско наречје ијекавског изговора отворило могућност за уједињење Јужних Словена, ${ }^{17}$ при чему су Срби који се тим изговором служе, у Хрватској, Црној Гори, Босни и Херцеговини и у западној Србији, „важна спона између Хрвата и Срба у цјелини“ (1979: 13). У примарном друштвенополитичком контексту, опет, у којем је хрватски језик већ добио легитимитет као од српског језика различита, аутохтона појава, ова Кораћева расправа није била само филолошка. ${ }^{18}$

Када Кораћ, међутим, каже да „књижевне границе између Срба и Хрвата [...] само језиком нису одређене“ (1979: 14), он имплицира да велики делови хрватске и српске књижевности настају на истом језику, због чега филолошки критеријум у овом контексту губи на важности, али и да су то међусобно веома удаљене традиције, тако да њихово разликовање не би требало да

${ }^{17}$ Културна историја Срба у 20. веку на је то, међутим, бацила другачије светло: опредељивање припадника Илирског покрета за штокавско наречје, чији су говорници чинили претежни део становништва Славоније, Далмације и Босне, и вековима били мета римокатоличког прозелитизма, „водило [je] разједињавању Срба, а уједињавању католика штокаваца“ (Николић 2014: 479) и постало „ослонац асимилације, кроатизације Срба“ (ИвАнић 1998: 76). Тај процес је свој пуни израз добио управо у Građi za hrvatsku retrospektivnu bibliografiju knjiga 1835-1940 (Zagreb: Nacionalna i sveučilišna biblioteka, 1982-1999), у коју су уврштени ствараоци римокатоличке вероисповести, не само из побројаних региона, већ и они из Црне Горе.

${ }^{18}$ Кьижевна хрестиомайија је била предмет жестоких напада, и у Загребу и у Београду, јер се под књижевним заједништвом, за чије је нарушавање оптужена, подразумевало интегрисање српских писаца из Хрватске у хрватску књижевност: „То што су они устали из мртвих као српски писци само по себи сведочило је да се и српска заједница у Хрватској враћа из културног, и политичког, такође, небића у биће“ (Деретић 1996: 292). 
представља проблем - оне се разликују по свему осим по језику. ${ }^{19}$ Кораћ то све, нажалост, није описао, а оставио је отвореном и могућност постојања случајева у којима пресудну улогу у припадању српској, односно хрватској књижевној традицији могу да имају - лексичке разлике; филолошки критеријум од овога највероватније није могао да буде нејаснији, али ни радикалнији.

Иако Прерадовићева поезија великим својим делом овом критеријуму одолева, у Кораћевом избору из стваралаштва Срба у Хрватској овога пута није се нашла ни једна његова песма, већ му је у предговору посвећена следећа реченица: „У илиризму дјелује чувени пјесник Петар Прерадовић обрађујући теме и мотиве из цијелог српско-хрватског простора, јер је код њега био жив дух заједништва, као и код Острожинског“(КорАћ 1979: 14). Говорећи о великим писцима који су се „у крилу српског народа у Хрватској родили и васпитали“ (1979: 28), Кораћ издваја само Матавуља и Десницу. Ова његова одлука делује још загонетније када се узме у обзир да се у Кьижевној хрестиомайији нашло места за текстове Доситеја, Вука, Даничића и Змаја, чија су дела утицала на културно зближавање Срба и Хрвата.

Важно је, осим тога, да Кораћ у предговору указује на неопходност теоријског заснивања појма двојне припадности појединих писаца, како би шовинистички ${ }^{20}$ мотивисани покушаји разграничавања националних баштина били спречени: „У вези с тим поставља се питање: шта у српскохрватским условима значи територијални принцип, затим тематски принцип [...], па културноисторијски, тј. питање улоге културне и духовне традиције у формирању књижевне личности" (КорАћ 1979: 27).

Упркос томе, међутим, у идућој, најзначајнијој Кораћевој књизи, Преілеg књижевної раgа Срба у Хрвайској (1987), за Прерадовића није било места. Ауторови критеријуми су овога пута развијенији:

„Како је сваки писац припадник народа из кога потиче, поставља се питање: је ли он у свом књижевном и културном раду доиста и био у контакту са тим народом, или се од њега удаљио под притиском различитих околности од породичних до политичких и социјалних. Аутору је била пред очима ова веза са народом као главни критериј, мада је она у неким примјерима сасвим лабава и недосљедна. Важнији су, наравно, процеси који су се одвијали са гледишта српске народне свијести па је у њима настајала култура која је исказивала овај народ и обликовала његову духовну физиономију [...] Тема, нијансе у језику, политички погледи, употреба ћирилице пресудне су ознаке по којима писце стављамо у овај преглед, поред националне припадности“ (КоРАћ 1987: 8-9).

19 Ова претпоставка, темељна за разликовање српске и хрватске књижевне традиције код Станка Кораћа, доведена је у питање осамостаљивањем и стандардизацијом хрватског, а касније и босанског и црногорског језика, који су донедавно важили за регионалне варијанте српског.

20 У значењу речи „шовинизам“ у Кораћевом тексту појављује се искључиво реч „национализам“. 
Нешто касније у тексту, Кораћ овим критеријумима додаје и везе писаца са матичним установама (школама, часописима, политичким странкама), тематску оријентацију стваралаштва према политичким и културним питањима српског народа, а посредно и православну вероисповест.

Треба приметити да је у овој Кораћевој концепцији српска књижевност све мање полифона, како у погледу писма и језика, тако и у погледу симболичких традиција које посредује и изражава; уочљива је, с друге стране, тежња да она буде сведена на одређене, што јасније идеолошке константе, односно на српску књижевност као идеалан, једном занавек дат предмет. То је правац редуковања којим се српска култура у целини кретала током друге половине 20. века.

Што се Прерадовићевог случаја тиче, Кораћ се сажето изразио: „Поставило се питање како поступити са Прерадовићем, Миланом Огризовићем, браћом Војновић, па чак и са Харамбашићем? Прерадовић је споменут, није посебно обрађен“, каже он и додаје, „Прерадовића увијек треба споменути, али у мјери у којој је споменут у уводном поглављу“ (КорАћ 1987: 9); то је било све.

Иако наслов Преїлеgа имплицира да се у њему ради о стваралаштву Срба у Хрватској, Кораћ ту у ствари дискутује о границама српске књижевности, из које је Прерадовић, без икаквих аргумената, чак и без покушаја тумачења, једноставно искључен. С обзиром на то какав је Кораћев однос према Прерадовићу био на почетку његовог рада на очувању српске баштине у Хрватској, у Вјейром вијанима, не можемо се отети утиску да у овом његовом дистанцирању од песника има идеолошке контроверзе и превише онога што је, нажалост, остало неизречено.

Овај пример, истовремено, открива да решење проблема Прерадовићеве књижевноисторијске припадности и не треба тражити у односу између српског и хрватског модела националне културе, већ у Прерадовићевом односу према српској култури или, тачније, у односу српске културе према Прерадовићу.

То је први пут било тематизовано у тексту Владимира Ћоровића, „Петар Прерадовић према Србима“, објављеном у тематском броју Књижевно $j y \bar{\imath} a$ из 1918, а две године касније и у збирци Покретии и gела. С обзиром на несагласност идеја овог текста с контекстом његовог првог објављивања, као и на видни опрез с којим је његов аутор настојао да формулише своја запажања, и он се може сматрати контроверзним. Док се Први светски рат ближио крају а са њим и дуго очекивано уједињење Јужних Словена, Ћоровић пише о дубоким и непомирљивим културним разликама измећу Срба и Хрвата, као и између њихових књижевних традиција, које су производи „двају социјалних средина, односно двају друштвених психа“ (Һоровић 1920: 104). Он истиче Прерадовића као „најдоследнијег и највернијег песника народног јединства српскохрватског племена“ (Һоровић 1920: 108), али истовремено у документима проналази и вага његова изјашњавања у корист најпре српског а затим и хрватског идентитета, нарочиту пажњу посвећујући 
његовој полемици с Јованом Суботићем око илирског имена и латинице. Иако констатује поетичке везе Прерадовићеве са српском народном поезијом и са школом објективне лирике, Ћоровић закључује да је он „књижевном особеношћу Хрват“, те да је српским савременицима био „туђ и без интереса“ а због југословенског ентузијазма, чак и „сумњив“ (Ћоровић 1920: 118).

Овај Ћоровићев невелики текст одиграо је важну улогу у српској књижевној историји, јер је Јован Деретић његове закључке у потпуности усвојио и у својим их најважнијим делима, у Истиорији срииске књижевностии (1983) и у Пуйу срйске књижевностии (1996), мање-више само парафразирао.

У првој од споменутих књига, Деретић спомиње Прерадовића међу „,српским илирцима“ (1983: 313), Огњеславом Утјешановићем Острожинским, Николом Боројевићем и Божидаром Петрановићем, али уз важну примедбу: „Премда, бар у почетку, по народном осећању Србин, у свом књижевном и националном деловању био је изразито хрватски песник“, и додаје да су Срби у њему видели „песника једнојезичког блиског народа“ (1983: 313).

У Пуйу срйске књижевностии, Деретић је то своје мишљење донекле разјаснио, називајући Прерадовића „књижевним пребегом“ и „Србином који је постао хрватски писац“, променивши књижевну националност:

„У споровима између Срба и Хрвата деловао је с хрватских позиција и критиковао Србе, и то пре свега због њиховог зазирања од националног и књижевног стапања два народа [...] Ни Срби њега нису прихватали као свог песника. Иако је певао о српским темама, о Косову, Цару Душану, о Марку Краљевићу, њих је одбијао како његов хрватски идиом тако и његов национални интегрализам“ (ДЕРетић 1996: 283).

Из тога произилази да је, што због културно-политичких опредељења (заснованих на панславизму!), што због трагова хрватске лексике (својствене, мање-више, свим српским писцима из Хрватске), српски национални карактер Прерадовићевог дела експлицитно порекнут. Српска књижевна историја је, дакле, искључила Прерадовића, јер се није уклапао у њен наратив, у којем је национална самосвест аутора играла важну улогу, а југословенско опредељење почело да нарушава представу о културном идентитету српског народа.

Као што су Прерадовићева дела, у својству библиографске грађе, била

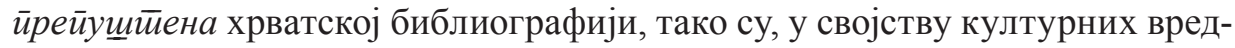
ности, била йрейщйена хрватској књижевној историји.

У том контексту, нарочито боли она реч „пребег“,21 коју је Деретић за Прерадовића неколико пута употребио, јер се налази у семантичком суседству речи „издајник“.22

21 „Хрвати су својим писцима који су стварали у српској књижевности давали погрдан назив пребези“ (ДЕРетић 1996: 281).

22 Да оваква парадигма националног књижевноисторијског наратива није довољно пространа, најбоље сведоче идеолошке доминанте у савременој српској књижевности, и то у делима и јавним наступима неких од њених најистакнутијих писаца, који, у духу глобализма, 
Почетком 1942. године, Хрватски издавалачки библиографски завод, на чијем је челу тада био у овом раду већ спомињани Мате Ујевић, објавио је антологију хрватског песништва у избору Љуба Визнера, уредника нацистичког часописа сугестивног наслова Сураgња у Берлину. У тој наизглед лепој књижици, Прерадовићева лирика нашла се на свега неколико страница од стихова Милета Будака, аутора усташког плана за решење српског питања. Обојица су, у надахнутом Визнеровом предговору, названи „пеsumnjivo sinovima svoga naroda, koji osjećaju zajedno s njime, plaču i raduju se s njime [...], jer je bol pjesnika zgusnuta patnja naroda, koji ga je rodio“(WIESNER 1942: 7).

Да апсурд буде страшнији, управо је у то време, у јулу 1941. и током 1942 , у логорима у Јадовну, Сланој и у Јасеновцу убијено неколико десетина Прерадовића из Грубишног Поља; ${ }^{23}$ на списку настрадалих налази се и један Петар Прерадовић.

Тек је Душан Иванић, у Къижевносӣи Срйске Крајине (1998), променом перспективе, проширио видике српске књижевне историје: „Српски илирци нису прихватили тај покрет да би се утопили у туђи племенски ентитет“, суптилно примећује он, „већ да би градили, како су вјеровали 'надплеменско' јединство“ (1998: 91). Из тога произилази и да Прерадовићево плутање по рубовима српског и хрватског културног идентитета није било последица стратегије „пребега“: прихватајући да учествује у хрватском културном контексту оплемењеном пансловенским месијанизмом, Прерадовић није претпостављао да ће бити похрваћен. „Тачно је, заправо, да је он пјесник јединства двају народа и јужнословенског простора и да у садашњој духовној констелацији нема правог уточишта“ (ИвАнић 1998: 91), као и да се „српска књижевност олако одрицала пјесника који је, прије Бранка Радичевића, носилац обједињавања европског пјесничког искуства и домаће усмене пјесничке традиције, црпећи и с једне и с друге стране у широким потезима оно што је било актуелно“ (ИвАнић 1998: 90). Подсећајући да ни остали крајишки романтичари нису укључени у прегледе српске књижевности романтизма, Иванић упозорава да

афирмишу изразито негативан па и нетрпељив или презрив однос према националним културним вредностима.

23 Упоредном анализом спискова идентификованих жртава НДХ, на званичним страницама Централне базе жртава Јадовна, Спомен подручја Јасеновац и Удружења потомака и поштовалаца жртава комплекса логора смрти НДХ Госпић - Јадовно - Паг, дошли смо до броја од тридесет девет убијених Прерадовића из Грубишног Поља. Доступно на http:// www.jusp-jasenovac.hr/Default.aspx?sid=7618, http://jadovno.com/arhiva/jasenovacke-zrtve-19411945-godine---popis.html_http://jadovno.com/imenicni-popis/\#.XMF-RGixXIU_приступљено 19. 4. 2019). 
„случај Петра Прерадовића треба посматрати принципијелно [...] у новим околностима, тај случај ће се понављати кад год је српски писац (својом вољом или под утицајем прилика) хтио да занијече своју основну припадност зарад геополитичког јединства двају народа на заједничком простору““ (ИвАнић 1998: 91).

Из ове перспективе сагледана, Прерадовићева фигура постаје репрезентативна и трагична.

Залажући се за равноправан третман Петра Прерадовића у српској и хрватској књижевној историји, Иванић наглашава да „данас тај [српски $\bar{u}$ рим. B. T.] идентитет из кроатоцентричног илиризма треба поново васпоставити“ (1998: 91). Стога он Прерадовићев опус сагледава у координатама српске књижевне историје, на нивоу књижевних појава, развоја и утицаја. ${ }^{24}$ Он указује на значај Вукове реформе за обликовање Прерадовићевих утопијских идеја о изградњи српскохрватског језика, повезује га са Бранком Радичевићем у погледу певања „на народну“, а неговањем мита о словенству са оним током српске књижевности који од Павла Соларића води ка Сими Милутиновићу Сарајлији и Ђорђу Марковићу Кодеру, отварајући на тај начин могућност за Прерадовићеву књижевноисторијску „репатријацију“.

Од првог издања ове Иванићеве студије прошло је већ пуних двадесет година.

Критеријуми за израду српске ретроспективне библиографије проширени су 2012. године, тако да су њен предмет коначно могли да постану и аутори српског порекла који су радили ван садашњих граница Србије, као и публикације у којима се пресецају културне баштине нација са простора бивше Југославије. То је омогућило завршетак двадесет првог тома Срйске библиоїрфије. Кьиїе 1868-1944, радно названог Дойунама (2017), у којем се, поред десетак антологија и читанки у које су уврштени Прерадовићеви стихови, налази још петнаест његових нових библиографских јединица (106.819-106.832, 108.657) - посреди су латинична издања песама, две преведене песничке збирке, на италијанском и на чешком језику, као и једно издање споменутог писма Вуку Караџићу (1897).

То, наравно, није све.

Најплоднији стваралачки период Петра Прерадовића, пета и шеста деценија 19. века, обухваћени су Срйском библиоірафијом. Кюиіе 1801-1867, чију израду приводи крају садашња генерација библиографа Народне библиотеке Србије, под руководством начелника, др Жарка Војновића. У њој је осамнаест библиографских јединица повезано с Прерадовићевим именом.

${ }^{24}$ Колико је нама познато, Божидар Пејовић је први аутор који је Прерадовићево дело разматрао у координатама српске књижевности, између Вука, Змаја и Његоша, иако га је у истом тексту посредно назвао и хрватским песником (PEJović 1973). 
Ту се, осим двеју његових ауторских песничких збирки, Pervenaca (1846) и Novih pjesama (1851), налазе и сви примери сарадње са српским часописима, од новосадске Даниие, Драїољуба и Зимзелена, Србско-яалмайинской маїазина, до песама у календарима и антологијама, које сведоче о заступљености па и о прихваћености Прерадовићеве лирике у српској средини за његовог живота.

То је све што је српска библиографија могла да учини за Петра Прерадовића. На реду је књижевна историја.

\section{ИЗВОРИ И ЛИТЕРАТУРА}

БАртуловић, Нико. Политички назори П. Прерадовића. Književni jug 6 (1918): 239-246. Витошевит, Драгиша. Уклето благо. Полийика 5, бр. 228 (7. јануар 1984): 10. ГАвриловић, Андра. Знаменийи Срби ХІХ века. Београд: Научна КДМ, 2008. Георгијевић, Крешимир. Петиар Прераgовић. Нови Сад: Матица српска, 1971. Деретић, Јован. Исӣорија срӣске књижевносиии. Београд: Нолит, 1983.

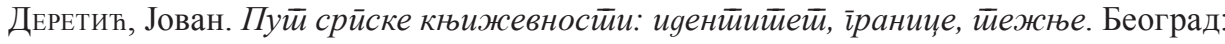
СКЗ, 1996.

Живанов, Миодраг. Предговор. Срйска библиойрафија. Књиїе 1868-1944. Књ. 14, хіiі-хх.

Приредили Миодраг Живанов и др. Београд: Народна библиотека Србије, 1989. Иванит, Душан. Књижевностй Срйске Крајине. Београд: Бигз, Чигоја штампа, 1998.

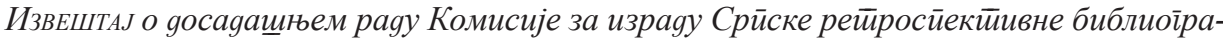
фије йри Нарояној библиоеиеичи у Беоіраgу (архива НБС).

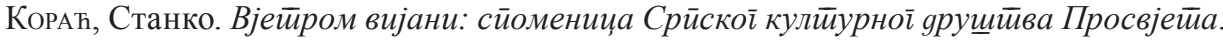
Загреб: Просвјета, 1971.

Кораћ, Станко (ур.). Књижевна хрестиомайија: из кулииурне бащииине срииской нароgа у Хрвайској. Загреб: Просвјета, 1979.

Кораћ, Станко. Преїлеg књижевної раgа Срба у Хрвайској. Загреб: Просвјета, 1987. КрстАновић, Здравко. Песник без биографије. Полийика, 31. марта 2018.

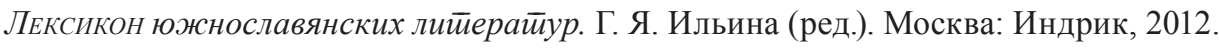
ЛомпАР, Мило. Дух самойорицања: йрилой крийици срйске кулйурне йолийике. Београд: Catena mundi, 2017.

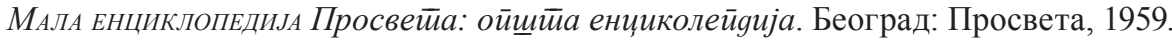

Николић, Ненад. Хрватско питање у Историји српске књижевности Стојана Новаковића. Зборник Майице срӣске за књижевности и језик 62/2 (2014): 477-505.

Новаковић, Стојан. Истиорија срйске књижевносиии: йреїлеg уїађан за щкколску уйойребу. Београд: Државна штампарија 1867.

Новаковић, Стојан. Истиорија срйске књижевностии: ӣреїлеg уїађан за щиколску уйойребу. Друіо са свим иррерађено изяање. Београд: Државна штампарија 1871.

Новаковић, Стојан. Срйска библијоірафија за новију књижевности 1741-1867. Београд: Завод за уџбенике и наставна средства, 2001. 
РАдојчић, Јован С. Биоірафије: Срби зайаяно оg Дунава и Дрине. Нови Сад. Прометеј, 2009.

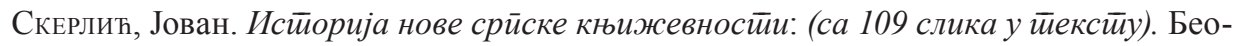
град: Издавачка књижарница С. Б. Цвијановића, 1914.

СРПСКА БИБЛИоГРАФИЈА. Къиї 1868-1944. Књ. 1-20. Миодраг Живанов (гл. ред.). Београд: Народна библиотека Србије, 1989-2008.

СРПСКА БИБЛИогрАФИЈА. Къийе 1868-1944. Књ. 21 - Допуне. Марија Богдановић и др. (прир.). Београд: Народна библиотека Србије, 2017.

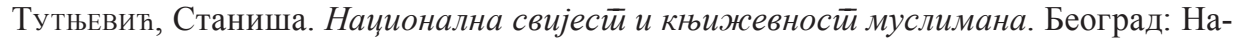
родна књига, Институт за књижевност и уметност, 2004.

Ћоровић, Владимир. Петар Прерадовић према Србима. Покретии и gела, 103-119. Београд: Издавачка књижарница Геце Кона, 1920.

Шевић, Милан. О Петру Прерадовићу. Песме Пейра Прераgовића: са увоgом, ӣyмачем и речником, iii-хvіi. Београд: Књижарница Велимира Валожића, 1902.

Arnautovitch, Alexandre. Un poète de l'unité Yougoslave. Paris: Ligue des universitaires Serbo-Croato-Slovènes, 1919.

Barac, Antun. Hrvatska književnost: od Preporoda do stvaranja Jugoslavije. Knj. 1, Književnost ilirizma. Zagreb: Jugoslavenska akademija znanosti i umjetnosti, 1964.

BEŠIĆ, Vinko. Preradović - pjesnik i general. Vijenac: književni list za umjetnost, kulturu i znanost 635 (2018). <http://www.matica.hr/vijenac/635/preradovic-pjesnik-i-general-28071/> 15. 4. 2019.

Flaker, Vida, ur. Preradovićev muzej. Pitomača: Odbor za proslavu 150-godišnjice rođenja hrvatskog pjesnika Petra Preradovića, 1968.

GAZDEK, Goran. Preradović i Čokonaj. <https://www.dw.com/sr/preradovi\%C4\%87-i \%C4\%8Dokonaj/a-47564345> 15. 4. 2019.

GRAĐA za Leksikon pisaca Jugoslavije. Novi Sad: Matica srpska, 2014.

ENCIKLOPEDIJA Leksikografskog zavoda. Zagreb: Jugoslavenski leksikografski zavod, 1962. HARni, Slavko. Jugoslavizam i kriteriji hrvatske retrospektivne bibliografije: bibliografski prijepori iz 1955. Vjesnik bibliotekara Hrvatske 47/3-4 (2004): 57-85.

HISTORY of the Literary Cultures of East-Centar Europe: junctures and disjunctures in the 19 th and 20th centuries, Volume III. Edited by Marcel Cornis-Pope and John Neubauer. Amsterdam, Philadelphia: John Benjamins Publishing Company, 2007.

JUGOSLOVENSKI književni leksikon. Novi Sad, Matica srpska, 1971.

KAŠAnIN, Milan. O Petru Preradoviću: povodom njegove stogodišnjice rođenja. Ljubljanski zvon (1918): 246-250.

KNJIŽEVNI JUG 1, br. 6 (1918). <http://www.digitalna.nb.rs/wb/NBS/casopisi_pretrazivi_po_ datumu/P_0261/1918/03/b006\#page/0/mode/lup> 15. 4. 2019.

Magjer, R. F., ur. U spomen stogodišnjice rođenja Petra Preradovića. Osijek: Klub hrvatskih književnika, 1918.

Maraković, Ljubomir. Petar Preradović. Zagreb: Hrvatsko kulturno društvo sv. Ćirila i Metoda, 1969. 
NiKČEviĆ, Milorad. Na civilizacijskim ishodištima: književni suodnosi i interferencije.

Osijek: Crnogorsko kulturno društvo Montenegro-Montenegrina, 1999.

O Petru Preradoniću danas: posebo izdanje časopisa Kritika. Zagreb, 1970.

PAvletić, Krsto. Petar Preradović, 18. III 1818 - 18. III 1918. Zagreb: Kr. zemaljska tiskara, 1918.

Pejović, Božidar. Život iza distance. Jakšić - Preradović. Izabrane pjesme, 85-95. Sarajevo: „Veselin Masleša“, 1973.

PRAVILNIK o radu Komisije za izradu Srpske retrospektivne bibliografije i o organizaciji rada na ovoj bibliografiji (архива НБС).

Preradović, Petar. Nove pjesme. U Zagrebu: Tisak F. Župana, 1851.

Preradović, Petar. Pervenci: različne piesme. U Zadru: Tiskom Demarchi-Rougier'ovim, 1846.

Rızvić, Muhsin. Interpretacije iz romantizma II. Sarajevo: Svjetlost, 1984.

VodnIK, Branko. Petar Preradović: studija. Zagreb: Tiskara Terezije Fišer, 1903.

VoDNIK, Branko. Petar Preradović kao slavenofil. Kniževni jug 6 (1918): 210-219.

ZAPISNIK druge sednice Komisije za izradu retrospektivne srpske bibliografije, održane 3 septembra 1954 и prostorijama Narodne biblioteke и Beogradu (архива НБС).

ZAPISNIK osme sednice Komisije za izradu retrospektivne srpske bibliografije, održane 23 juna 1955 godine u Narodnoj biblioteci и Beogradu (архива НБС).

ZAPISNIK prve sednice Komisije za izradu retrospektivne srpske bibliografije, održane 20 jula 1954 godine u prostorijama Narodne biblioteke и Beogradu (архива НБС).

WIESNER, Ljubo, ur. 42. Zagreb: Hrvatski izdavalački bibliografski zavod, 1942.

Vesna M. Trijić

\section{PETAR PRERADOVIĆ IN SERBAIN RETROSPECTIVE BIBLIOGRAPHY AND LITERARY HISTORY}

\section{Summary}

In this paper, we will use the position which in Serbian retrospective bibliography and literary history occupies the work of the romantic poet Petar Preradović, a Serb from Croatia, a Roman Catholic and a proponent of the Yugoslav idea, as an example of the logic and consequences of the process of radical narrowing of the concept of Serbian national identity during the 20th century. Instead of differences between the Serbian and the Croatian model of national culture, we will dwell on the ideology that Serbian culture manifested through its changing attitude towards Preradović.

Народна библиотека Србије

Одељење за библиографију

Скерлићева 1, 11000 Београд

trijicvesna@gmail.com 